\title{
Determinants of Corporate Environmental Disclosures in Sri Lanka: the role of Corporate Governance
}

\author{
M.N.F. Nuskiya \\ Department of Business Finance \\ Faculty of Management, University of Peradeniya \\ nuskimnf@gmail.com \\ E.M.A.S.B. Ekanayake \\ Department of Business Finance \\ Faculty of Management, University of Peradeniya \\ athulae@gmail.com \\ Eshani S. Beddewela \\ University of Huddersfield Business School \\ Queensgate \\ Huddersfield HD1 3DH \\ United Kingdom \\ e.s.beddewela@hud.ac.uk
}

\begin{abstract}
Ali M. Gerged*
(Corresponding Author)

Leicester Castle Business School

De Montfort University

The Gateway, Leicester, LE1 9BH, UK

ali.gerged@dmu.ac.uk

Faculty of Economics

Misurata University

Misurata City

PO Box 2478, Libya
\end{abstract}

Cited as: Nuskiya, M., Ekanayake, E, Beddewela, W., \& Gerged, A., M. (2021). Determinants of Corporate Environmental Disclosures in Sri Lanka: the role of Corporate Governance. Journal of Accounting in Emerging Economies, Forthcoming: DOI: 10.1108/JAEE-02-2020-0028 


\begin{abstract}
Purpose - This study explores the levels of, and trends in corporate environmental disclosure (CED) among a sample of Sri Lankan listed companies from 2015 to 2019. Further, this article examines the firm-level determinants of CED, including corporate governance (CG) mechanisms, in Sri Lanka from a multi-theoretical perspective.

Design/methodology/approach - Using a sample of 205 firm-year observations, this paper distinctively applies a panel quantile regression (PQR) model to examine the determinants of CED in Sri Lanka. This method was supported by estimating a 2-step generalised method of moment (GMM) model to tackle any possible existence of endogeneity concerns.

Findings - Our findings indicate an increasing trend in CED practice among the sampled companies (i.e., 41 firms, the only adopters of the GRI framework) in Sri Lanka from 2015 to 2019. However, it is still considered at an early stage compared with other developed counterparts. Furthermore, this study suggests that board size, board independence, board meetings, industry type, profitability and firm size are positively associated with CED level. In contrast, and consistent with our expectation, CEO duality is negatively attributed to the disclosed amount of environmental information in the Sri Lankan context.
\end{abstract}

Research limitations/implications - Our empirical evidence reiterates the crucial need to propagate and promote further substantive CG reforms, mandating CED in Sri Lanka.

Originality/value - Our findings provide much-needed insights for indigenous companies, operating across similar emerging economies, to understand how CED can be incorporated into their reporting process based on the GRI framework in order to enhance their firm value, reduce legitimacy gaps and mitigate other operational risks.

\title{
Keywords:
}

Corporate Environmental Disclosure, Emerging Economies, Firm-Specific Characteristics, Agency Theory, Legitimacy Theory, Stakeholders Theory, Sri Lanka

\section{Research Paper}




\section{Introduction}

Global economic development has generated detrimental environmental impacts such as carbon emissions, global warming, and natural disasters. Corporations have thus been compelled to engage proactively in Corporate Environmental Disclosures (CED) (Belal and Momin, 2009; Belal et al., 2010; Campbell, 2004; Gerged et al., 2021a) to mitigate the potential risks to their financial and economic sustainability created by their environmental practices (Gray, 2000). CED is defined by Wilmshurst and Frost (2000) as the impact of business operations and activities on the natural and physical environment in which the company operates. Campbell (2004) provided a more aggregated understanding of CED by identifying different types of Environmental Disclosures consisting of those related to the company's attitude, policy or behaviour towards its environmental impacts, emissions, pollution, cleaning up (after pollution), re-landscaping or energy efficiency. Thus, CED can be identified as a means to discharge the responsibility of companies' operations towards the environment in various aspects.

There has been a noticeable intensification of environmental disclosures in annual reports in both developed and developing countries (Albitar et al., 2020; Agyei and Yankey, 2019; Belal et al., 2010; Deegan and Gordon, 1996; Gerged et al., 2021b; Kolk, 2004; Jariya, 2015; Mohmed et al., 2019; Salem et at., 2020). For instance, a survey conducted by KPMG with 4100 companies located across 41 countries concluded that 93 percent of the world's largest 250 companies use their annual reports to reveal the impact of their businesses on environment and society, with noticeable growth in CED across emerging economies (KPMG, 2013). One could, therefore, argue that the modern era of external reporting has compelled firms to expand the scope of the disclosure in annual reports, beyond those of the mandatory economic and financial disclosures towards social and environmental disclosures.

In this regard, there is compelling evidence to affirm the growth of CED across developed countries (Deegan and Gordon, 1996; Deegan et al., 2002; Campbell, 2004; Hogan and Lodhia, 2011). The growth of CED in developing countries, however, remains limited (Gerged et al., 2018; Gerged et al., 2021b; Mahadeo et al., 2011, Amran and Siti-Nabiha, 2009), even amidst concerted efforts by companies in these countries to replicate the disclosure practices of developed countries through the adoption of internationally recognized accounting rules and regulations (Belal, 2001). Belal and Cooper (2011) argue that this is due to firms' reluctance to disclose sensitive or confidential information, specifically those related to environmental responsibilities, coupled with a compelling 
need to publish brief annual reports that are not conducive to CED. The absence of mature investororiented market systems, supported by proficient institutional systems, too could be another reason for this low-level of CED in developing countries (Orazalin and Mahmood, 2019). With specific regard to CED amongst Sri Lankan companies, we can identify variations, with some companies engaging in fulfilling their environmental responsibilities but not disclosing those practices, and with others engaging in CED primarily for greenwashing purposes (Jariya, 2015).

There is a dearth of extant empirical research from developing countries, pertaining to environmental and social accounting and disclosure in general (Adhariani and du Toit, 2020; Belal, 2001; Belal and Cooper, 2011; Diab and Metwally, 2020; Gerged et al., 2020a; Welbeck et al., 2020). For instance, most extant disclosure studies are focused upon developed countries such as Australia, the United Kingdom and Europe (See Robert, 1991; Gray et al., 1995; Deegan and Gordon,1996; Deegan et al., 2002; Campbell, 2004; Cowan and Gadenne, 2005; Rao et al., 2012; Burgwal and Vieira, 2014; Yu and Zhao, 2015; Albitar et al., 2020) and upon emerging economies such as Malaysia, Hong Kong and China (e.g., Gao et al., 2005; Smith et al., 2007; Qu et al., 2013). In relation to those studies which have been conducted in developing countries, environmental disclosure (or CED) is considered as an aggregate part of the firm's overall corporate social disclosure (CSD), thus, limiting the potential to identify firmlevel CED in a more specific manner (Gray et al., 1995; Milne and Adler, 1999; Unerman, 2000; Belal, 2001; Jamali et al., 2008; Amran and Devi, 2007; Belal and Momin, 2009; Khan et al., 2012; Gerged et al., 2018). Thus, there is a need for more studies examining CED and its determinants, specifically from developing country contexts.

In this regard, Sri Lanka presents a unique and dynamic context for the study of CED. Sri Lanka is a middle-income country located in South Asia, with a population of 20.48 million people (World Bank, 2015). In Sri Lanka, in May 2009, the Sri Lankan economy has been growing steadily with the end of the armed conflict, driven by an inflow of foreign direct investments and far-ranging infrastructure development programme (IPS, 2014). Nevertheless, this rapid industrial growth has also resulted in detrimental environmental impacts, such as pollution and ecological imbalances. While pro-active governmental actions, primarily in the form of environmental regulations and policies ${ }^{1}$, have been undertaken to monitor and control corporate environmental practices, there are as yet deficiencies in relation to the reporting and disclosure of corporate environmental information. In this regard, with

\footnotetext{
1 National Environmental Act, Forest ordinance, Cost Conservation Act, National Environment Policy, National Watershed Management Policy, Cleaner Production Policy, National Biosafety Policy, National Policy on Solid Waste Management
} 
the extant accounting norms and culture predominantly focusing upon perfecting the technical aspects of accounting, there is a dearth of locally developed reporting standards to address the need for CED in the country (Pramanik et al., 2008; Akisik and Gal, 2011; Sarivudeen and Sheham, 2013; Rajeshwaran and Ranjani, 2013).

Nevertheless, stakeholder pressures upon Sri Lankan listed companies to engage in CED has been on the increase (Sarivudeen and Sheham, 2013), as reflected in evidence supportive of increased CED in recent studies, although marked sector-specific variations have been identified in this regard (Rajeshwaran and Ranjani, 2013). Thus, questions remain as to whether companies operating in environmentally sensitive sectors (for instance) are engaging in CED, to the same (or even a greater) extent than those companies operating in less polluting sectors. We also do not know the level of transparency of CED within those companies who do disclose, for instance, are these companies reporting selective information which is of a positive nature, thereby engaging in 'greenwashing' aimed at building their corporate reputations, rather than engaging in CED in a transparent manner?

Besides, previous scholarship suggests that corporate compliance with good CG arrangements can be positively attributed to increasing CED (e.g., D'Amico et al., 2016; Ezhilarasi and Kabra, 2017; Fernandes et al., 2019; Gerged, 2020). In Sri Lanka, the first draft of the Sri Lankan Corporate Governance Code (SLCGC) was established in 1997 by the institute of chartered accountants. This draft was subsequently reformed in 2003, 2008, 2013, and most recently in 2017. This poses questions about the role of board characteristics in improving CED status in Sri Lanka, which has not been sufficiently addressed by prior work (e.g., Mudiyanselage, 2018; Kengatharan \& Sivakaran, 2019).

Our study, therefore, addresses these queries and contributes to the existing body of CED literature in developing economies by (i) exploring the latest levels of, and trends in CED among a sample of the only adopters of the GRI framework in Sri Lanka from 2015 to 2019, and (ii) also by investigating the micro-level determinants of CED, including CG, in Sri Lanka using a panel quantile regression (PQR) model from a multi-theoretical perspective.

Our findings are two-fold. First, our empirical evidence indicates an increasing trend in CED practice among the sampled companies (i.e., 41 firms, the only adopters of the GRI framework) in Sri Lanka from 2015 to 2019, although it is still considered at an early stage compared with other developed counterparts. Furthermore, this study suggests that board size, board independence, board meetings, industry type, profitability and firm size are positively determining the level of CED. In contrast, CEO 
duality is negatively attributed to the disclosed amount of environmental information in the Sri Lankan context.

In doing so, we contribute to extant CED literature in relation to developing countries in the following ways; first, our study evaluates the environmental disclosures based on the Global Reporting Initiative (GRI) guidelines. We purport that evaluating the quality of environmental disclosures in line with the GRI Index is likely to improve the validity of our study (Cormier et al., 2011), due to its global acceptance as an established environmental reporting framework (Azim et al., 2011), thus enabling us to engage in comparative evaluations of our findings with those of other similar studies, which have also been based on the GRI index. Second, our findings provide much-needed insights for indigenous companies, operating across similar developing country contexts, to understand the ways in which CED can be incorporated into their reporting framework to enhance their firm value (Cormier et al., 2011; Wang et al., 2013) and reduce legitimacy gaps and mitigate their operational risks (Wang et al., 2013). In doing so, our paper meets calls for more normative research in this regard (Sumiani et al., 2007). Third, this research's findings also contribute towards assisting stakeholders, specifically indigenous investors, to evaluate the adequacy of companies' environmental responsibilities by examining their CED practices (Cormier et al., 2011; Azim et al., 2011; Wang et al., 2013). Fourth, using a panel quantile regression (PQR) model, we apply one of the most appropriate statistical estimations, which offers a more comprehensive understanding of CED determinants in Sri Lanka than prior work that was confined to the traditional least-squares method. Fifth, unlike previous studies, we estimate a 2-step GMM model to overcome the endogeneity concerns and ensure that our results are reasonably robust and reliable. Finally, we offer the latest update regarding the firm-level determinants, including CG, of CED in Sri Lanka from 2015 to 2019.

The rest of the paper is structured as follows. Section two introduces the theories and the relevant literature used to develop the study's hypotheses. Section three outlines the methods used in the study. Results and discussion are presented in the penultimate section, and our concluding remarks are provided in the final section.

\section{Theoretical underpinning, related studies and hypotheses development}

\subsection{Related Studies:}

The extant voluntary disclosure studies in Sri Lanka are confined to examining 'social' disclosure or 'sustainability' reporting (See Dissanayake et al., 2016; Dissanayake et al., 2019; Guthrie and 
Abeysekera, 2006; Beddewela and Herzig, 2013; Niresh et al., 2018), with only a few studies examining CED (Jariya, 2015; Rajeshwara and Ranjani, 2013). Likewise, fewer studies have considered CG mechanisms as determinants of social and/or sustainability disclosures in Sri Lanka (e.g., Mudiyanselage, 2018; Kengatharan \& Sivakaran, 2019). Collectively, the existing longitudinal studies are limited in the scope of their empirical focus - i.e. having focused on periods of study that are less than five years and being focused upon one or two sectors and have used quantitative content analysis to measure social/sustainability disclosures. For example, recently, Dissanayake et al. (2019) employed a quantitative content analysis technique based on word counts to explore the levels and determinants of sustainability reporting in Sri Lanka from 2012 to 2015. This study found that firm size and usage of the GRI guidelines are the most relevant sustainability reporting drivers in Sri Lanka. However, it did not specifically examine CED's determinants as a dimension of sustainability reporting ${ }^{2}$ in the regression analysis, which does not sufficiently address the gap mentioned above in the extant body of literature.

Similarly, Mudiyanselage (2018) was confined to using a dichotomous process to measure sustainability reporting in Sri Lanka from 2012 to 2013, where a score of "0" was given if a firm did not publish a sustainability report and "1" otherwise. Most relatedly, Jariya (2015) explored CED's level in Sri Lanka using a quantitative content analysis technique based on word counts during the 2011/2012 fiscal year. This study was also limited to examining the effect of firm size on CED, only. Also, previous studies were limited to using the least-squares method to run the statistical analysis such as the logistic regression (Mudiyanselage, 2018) and the ordinary least squares (OLS) regression (Kengatharan \& Sivakaran, 2019). Additionally, previous studies in Sri Lanka did not address endogeneity concerns to the best of our knowledge, which raises doubts regarding the robustness of their findings. This backdrop provides us with an interesting context in which to undertake the current study. Therefore, our paper aims to identify the latest trends in CED among the adopters of the GRI guideline in the Colombo Stock Exchange (CSE) from 2015 to 2019. This study also contributes to the existing body of literature by investigating the extent to which firm-specific determinants, including CG, can influence the degree to which firms disseminate their environmental information in Sri Lanka.

\subsection{Corporate Governance and Agency Theory:}

2 Sustainability reporting consist of three main dimensions, namely economic sustainability, environmental sustainability and social sustainability (Gray et al., 1995). 
The institute of chartered accountants in Sri Lanka has been at the forefront of issuing and reforming CG codes in Sri Lanka. The first draft of the Sri Lankan Corporate Governance Code (SLCGC) was established in 1997 and titled as the code of the best practices on matters related to corporate governance's financial aspects. The SLCGC was reformed in 2003, 2008, 2013, and most recently in 2017. This motivated our study to examine how CG structures can determine CED level in Sri Lanka, specifically after the recent reform. Prior studies suggest that compliance with good CG arrangements can be positively attributed to increasing firms' dissemination of environmental information (AlGamrh et al., 2020; Ezhilarasi and Kabra, 2017; Gerged, 2020; Fernandes et al., 2019; Mathuva et al., 2019). Specific board structures are related to a more dynamic role for CG mechanisms in controlling managers opportunistic behaviour, and thus, bringing into line their interests with those of shareholders (D'Amico et al., 2016; Gerged, \& Elheddad, 2020; Gerged \& Agwili, 2020; Gerged et al., 2020b; Matuszak et al., 2019; Salem et al., 2019). We seek to examine the impact of board characteristics on CED in the Sri Lankan setting.

\subsubsection{Board size and CED}

Previous empirical evidence brought up different thoughts regarding the impact of board size on CED. For example, Beiner et al. (2004) state that the small size of a board can minimise its capacity for monitoring managements' behaviour, which, therefore, reduces its efficiency. In contrast, Ahmed et al. (2006) argue that smaller boards effectively reduce agency conflicts. More relatedly, other researchers confirm that a large board is more likely to support corporate engagement in CED practices (Rao et al., 2012; Mudiyanselage, 2018; Liao et al., 2015; Tauringana and Chithambo, 2015; Trireksani and Djajadikerta, 2016; Ezhilarasi and Kabra, 2017; Wang, 2017; Jizi, 2017). Because a largesized board is expected to include more independent and experienced members who can monitor managers activities and work on decreasing the asymmetric gap of environmental information (Ntim \& Soobaroyen, 2013; Giannarakis et al., 2019). For instance, Rao et al. (2012) and Akbas (2016) are suggestive of a positive and significant association between board size and CED in Australia and Turkey, respectively. According to the Sri Lankan Corporate Governance Code (SLCGC) (2013; 2017), the board's number is not explicitly mentioned, though it should be enough and appropriate for the effective decision-making process. As such, the first hypothesis aims to examine the impact of board size on CED in the Sri Lankan context as follows:

H1: Ceteris paribus, there is a statistically significant positive relationship between the board of directors' size and CED in Sri Lanka.

\subsubsection{Board independence:}


Independent non-executive directors on boards appeared to have a strong motivation to act as efficient monitors, and not to collude with managers to expropriate the wealth of owners (Fama, 1980) as their value in the market is highly reliant on the extent to which they are independent as directors (Fama and Jensen, 1983). Agency theory states that board independence is an effective mechanism in reducing managerial opportunism (Fama and Jensen, 1983). To give credibility to this notion, previous empirical evidence such as Liao et al. (2015), Mudiyanselage (2018), Fernandes et al. (2019), and Gerged (2020) points out that independent directors seemed to advocate the dissemination of environmental information as a tactic geared towards taking on a balanced accountability process. Stating differently, board independence is expected to be positively associated with CED in different settings worldwide. In Sri Lanka, based on the SLCGC (2013; 2017), at least one-third of the directors should be independent. This poses the question of what we mean by independent directors in this context? The independent director can be defined as a member who is not associated with the firm, or any of its top managers, affiliate firms, or its external auditors by any kind of interests, mainly financial interests, or relations apart from his/her shareholding in the firm, which can affect his/her decisions or lead to exploitation of his/her position in the firm (Gerged, 2020). Thus, our study is motivated to examine the influence of having an appropriate number of independent directors on CED in Sri Lanka. The second hypothesis is:

H2: Ceteris paribus, there is a statistically significant positive relationship between the board of directors' independence and CED in Sri Lanka.

\subsubsection{Board Meeting frequency:}

A robust body of literature suggests that the directors' meeting frequency has a positive impact on CED. For instance, Primary and Rahardja (2013) and Setyawan and Kamilla (2015) argue that board members' frequency is positively attributed to CED in Indonesia. In other words, the frequency of board meetings seems to lead to more effective oversight of managers' opportunistic behaviour, which, in turn, may result in more extensive reporting on environmental information (Setyawan and Kamilla, 2015). The Sri Lankan CG code of 2017 says that the board of directors should meet regularly. More specifically, directors should meet at least once in each quarter of a fiscal year to effectively perform the board's responsibilities (SLCGC, 2107). Thus, we develop the following hypothesis:

H3: Ceteris paribus, there is a statistically significant positive relationship between a board meeting and CED in Sri Lanka.

\subsubsection{CEO Duality:}


The duality of a Chief Executive Officer (CEO) occurs when one person simultaneously holds the two positions of CEO and Chairman (Prado-Lorenzo and Garcia-Sanchez, 2010). Theoretically, CEO duality can surge the risk that the CEO perhaps will undertake strategies, which maximise his/her own interest to the firm's detriment (Jensen and Meckling, 1976). Some prior studies concluded a negative connotation between CEO duality and CED, indicating that CEO duality may lead to conflicts of interest, and therefore, it might affect the transparency process of a given firm (e.g., Alfraih, 2016; Chau and Gray, 2010; Freitas Neto and Mol, 2017). In Sri Lanka, the SLCGC (2013; 2017) states that the CEO and the Chairman must have different roles in the firm to avoid conflicting interests and maintain an effective monitoring process. This means that the board of directors is recommended to employ a non-executive independent director for Chairman's position. Consistent with the SLCGC (2013; 2017), and based on a significant body of prior studies, we presume that CEO duality can deteriorate boards' independence and expand the information asymmetry issue. The fourth hypothesis is as follows:

H4: Ceteris paribus, there is a statistically significant negative relationship between the CEODuality and environmental disclosure in Sri Lanka.

\subsection{Industry Type and Legitimacy Theory}

Multiple studies have highlighted an upward trend in CED across time in terms of the number of companies and the amount of environmental information in annual reports (e.g., Walden and Schwartz, 1977; Deegan and Brown, 1998; Litic, 2008; Deegan et al., 2002; Azim et al., 2011; Beddewela and Herzig, 2013). The underpinning theoretical justification across these studies have been provided primarily through legitimacy theory, although other theories such as stakeholder theory, agency theory, signalling theory and media agenda setting theory have also been widely used to explain the practice of CED (Campbell, 2004; Akhtaruddin, 2005). Our paper draws upon a dual theoretical model, namely, legitimacy theory and stakeholder theory to explain the relationships posited in this study.

In using legitimacy theory to explain CED (Wilmshurst and Frost, 2000; Cowan and Gadenne, 2005; Akhtaruddin, 2005; Tregidga et al., 2006; Amran and Siti - Nabiha, 2009; Azim et al., 2011), scholars have focused upon Suchman's (1995; p 500) definition of legitimacy as "a generalized perception or assumption that the actions of an entity are desirable, proper, or appropriate within some socially constructed system of norms, values, beliefs, and definition". Thus, legitimacy is a socially constructed perception (or assumption) by external stakeholders, with regard to acceptable corporate practices 
(Tregidga et al., 2006). The strategic approach to legitimacy propagated initially by Salancik \& Pfeffer (1978) and later by Oliver (1991), Ashforth and Gibbs (1990) and Suchman (1995), emphasizes how organizations could pro-actively manage legitimacy constituted upon them by external stakeholders. This approach views legitimacy as an operational resource (Ibid), which the organization can manage and directly influence (Ashforth and Gibbs, 1990). In taking up this instrumental/strategic view of legitimacy, gaining legitimacy is purposive and calculated (Suchman, 1995), and the company asserts managerial control over the process of legitimization.

CED can be identified as a legitimation tool, enabling corporations' process of legitimization (Tilt, 2009; Brown and Deegan, 1998). In this regard, CED empowers corporations to provide evidence of their environmental accountability (Sumiani et al., 2007), thereby, enabling them to gain legitimacy from salient stakeholders (Deegan and Gordon, 1996; Brown and Deegan, 1998; Deegan et al., 2002; Azim et al., 2011; Mahadeo et al., 2011). Previous scholars have ascertained that companies do use CED, to gain strategic legitimacy specifically through the provision of information in relation to the corporations' environmental performance, thereby further substantiating the transparency and accountability of their environmental performance (Wilmshurst and Frost, 2000; Alewine and Stone, 2013; Cowan and Gadenne, 2005; Tregidga et al., 2006; Burgwal and Vieira, 2014).

However, as different industries comprise different characteristics (i.e., the risk to society, potential growth, employment opportunities, competition, and government interference), consequently, CED's nature and patterns also vary amongst these sectors (Gao et al., 2005). The findings of extant empirical studies provide support for this notion (e.g., Gray et al., 1995; Gao et al., 2005; Clarkson et al., 2010; Jariya, 2015), with several studies indicating that the industry classification influences the degree of environmental disclosure which are time and event-specific of certain categories of environmental information (Walden and Schwartz, 1977; Rizk et al., 2008; Jariya, 2015). These findings have implications from a legitimation perspective, as engaging in CED would be most important for those companies operating in environmentally sensitive sectors, due to their need to affirm their environmental accountability (Gao et al., 2005; Burgwal and Vieira, 2014) to salient stakeholders, as a precursor to gaining legitimacy from them.

Thus, the arguments of legitimacy theory and extant empirical research findings lead to the fifth hypothesis's development as follows.

H5: Ceteris paribus, there is a statistically significant positive relationship between the industry type and CED in Sri Lanka. 


\subsection{Company characteristics and Stakeholder Theory}

Stakeholder theory asserts the importance of considering the requirements of a wider range of people and interest groups who interact with the company (Azim et al., 2011) and who can assist or hinder the achievement of the organization's objectives. According to Jariya (2015), stakeholders identify business units not as an economic entity, but as a socio-economic entity.

Thus, according to stakeholder theory, a company should be able to balance conflicting demands of a wide variety of stakeholders, with unequal power over the organization. Based upon the managerial stream of stakeholder theory (Amran and Haniffa, 2011), while all of the organization's stakeholders can be argued to have an equal right for information pertaining to CED (Robert, 1992), managers could strategically manage the organization's relationship with the most salient stakeholders. In doing so, CED could become the means by which to enhance their relationship with stakeholders (Wilmshurst and Frost, 2000; Guthrie and Abeysekera, 2006; Said et al., 2009; Qu et al., 2013), specifically those powerful stakeholders who can influence the economic sustainability of the company (Gray et al., 1995). Thus, CED secures the relationship between a company and its stakeholders through effective communication of progress on sustainability (Azim et al., 2011).

On the other hand, Raar (2002) argues that environmental disclosure benefits are questionable for stakeholders' decision-making process because of their incomparable nature. In order to eliminate this drawback, he suggests adopting GRI principles as a standardized format for consistency in environmental disclosures.

Based on the tenets of stakeholder theory, company size and profitability have been identified as key CED determinants. Company size as a corporate characteristic determines CED (Amran and Haniffa, 2011; Jariya, 2015), from the perspective that larger companies can be argued to have a greater impact on corporate disclosures. Since, large companies are also likely to have more stakeholders compared to smaller companies (Jariya, 2015), in order to satisfy this wider variety of powerful stakeholders (Amran and Haniffa, 2011), larger companies would thus need to disclose more on the environment (Burgwal and Vieira, 2014).

Existing literature has shown mixed results over the relationship between company size and environmental disclosure. A number of studies (e.g., Gray et al., 1995; Raar, 2002; Gao, 2005; Cormier et al., 2011; Bhattarai, 2014; Burgwal and Vieira, 2014) have found a positive relationship between company size and environmental and social disclosures. Some have identified the cost as a constraint 
on CED, particularly in small and medium-sized companies (Burgwal and Vieira, 2014). Further, Rizk et al. (2008) argued that company size and its type might differ based on the complexity of their operations, and the availability of resources, which affects the level of environmental disclosures. However, several studies (e.g., Roberts, 1991; Smith et al., 2007) revealed otherwise in which they find that there is no significant relationship between firm size and corporate voluntary disclosure. Even in the Sri Lankan context, according to Jariya (2015), there is a negative relationship between firm size and CED based on 2011/12 annual reports. The notion of stakeholder theory and the empirical findings, as discussed above, lead to the development of the sixth hypothesis as follows.

H6: Ceteris paribus, there is a statistically significant positive relationship between firm size and CED in Sri Lanka.

Sumiani et al. (2007) indicated that excellent environmental performance is significantly related to good economic performance and CED. Thus, company disclosure on environmental impacts of the company establishes a strong corporate reputation and a brand image, enabling them to overcome the risk of under leveraging assets (Jariya, 2015). Shortcomings in communicating both financial disclosures and non-financial disclosures may adversely affect companies in obtaining advantages over competitors. For instance, if a company has performed well in both financial and non-financial terms, but has been limited to discussing its financial performance, this may have an adverse consequence in gaining competitive advantages. Accordingly, Azim et al. (2011) stated that CED could minimise the risk of powerful customer boycotts, save production costs and enable the company to gain competitive advantages. Hence CED of companies is likely to assist them in obtaining a competitive advantage through which they secure profits and their going concern (Clarkson et al., 2010; Amran and Haniffa, 2011; Burgwal and Vieira, 2014).

Although results varied, many studies have found a positive association between the level of environmental disclosures and profitability consistent with stakeholder theory. Akhtaruddin (2005) argued that companies tend to disclose more information on the environment if their profitability is high, whereas if their profitability is low, they communicate fewer details of the environment. Profitability is consistent with stakeholder theory views since well-performing firms disclose more to cater to a wide variety of stakeholders. For instance, Akhtaruddin (2005) stated that profitable firms tend to publish more on the environment to appease shareholders, enhance the marketability of investors' marketability, and justify compensation packages of managers. Further, Khan et al. (2012) also supported this argument by elaborating that profitability allows management to reveal more 
environmental and social information to stakeholders with freedom and flexibility. Following this notion, several studies have identified a significant relationship between firm profitability and their environmental disclosures (e.g., Gray et al., 1995; Smith et al., 2007; Cormier et al., 2011). Smith et al. (2007) has found a negative relationship between these two variables, whereas some studies (e.g., Burgwal and Vieira, 2014; Suttipun and Stanton, 2012) have found no significant association.

In line with the empirical findings and based on stakeholder theory, the study's seventh hypothesis is constructed as follows.

H7: Ceteris paribus, there is a statistically significant positive relationship between profitability and CED in Sri Lanka. 


\section{Research Design}

\subsection{Data and sample considerations:}

The study was drawn from Sri Lankan publicly listed companies, registered in the Colombo Stock Exchange (CSE) from 2015 to 2019 (i.e., 291 companies in total). The selected sample included 41 companies, which represented 15 per cent of the companies listed on the CSE and 36 per cent of the listed companies in the CSE, which report on the environment. Moreover, these were the only companies that adopted the GRI reporting framework to publish environmental responsibility information. The rest of the listed companies either did not report on the environment at all, or they did not follow the GRI reporting framework in this regard.

According to Jariya (2015), Sri Lankan companies disclose their environmental information in annual reports, company websites, and separate sustainability reports and newsletters. Data were collected from annual reports published from 2015 to 2019 of the 41 companies in the final sample resulting in 205 firm-year observations. It is a mandatory requirement for all listed companies on the CSE to publish annual reports. The use of annual reports to gather data can also be justifiable as many scholars have previously argued that managers use annual reports as a means of corporate communication to legitimize their operations primarily in the reporting of corporate social and environmental disclosures (Gray et al., 1995; Brown and Deegan, 1998; Kolk, 2004; Azim et al., 2011; Suttipun and Stanton, 2012; Jariya, 2015).

\subsection{Measures:}

Table 1 presents the operational definitions of our research variables. In testing the research hypotheses, we divide the measurement of the research variables into four stages. First, CED is measured using the GRI checklist used to collect environmental information from corporate annual reports over the period from 2015 to 2019. Second, CG mechanisms were measured using the board of directors' characteristics (i.e., the board size, independence, frequency of meetings, and CEOduality) using data were manually collected from annual reports from 2015 to 2019. Third, a set of firm-specific characteristics (i.e., firm size, profitability, and industry type) are employed to control for the association between CG and CED in the context of Sri Lanka (See Table 1). Third, to examine CED determinants in Sri Lanka, we innovatively apply a panel quantile regression (PQR) model that offers a more comprehensive analysis of this association than other traditional linear models such as the ordinary least squares (OLS) model. This method is also strengthened by running a generalised 
method of moment (GMM) model to overcome any statistical concerns connected to the potential occurrence of endogeneities.

\section{INSERT TABLE 1 HERE}

This study used content analysis to quantify CED. According to Krippendorff (2013), content analysis, is a technique to code a set of text into different categories depending on selected criteria. Moreover, content analysis is a method used to collect data under predetermined criteria by codifying qualitative and quantitative information to trace the presentation's patterns and reporting information (Guthrie and Abeysekera, 2006). Further, the study discussed three technical requirements for the content analysis criteria: clearly and operationally defined (unit of analysis); able to indicate whether an item belonged to a particular category or not (Data capture); and able to exhibit the reliability of data and/or instruments and the validity based on previous findings. Milne and Adler (1999) elaborated that the reliability of content analysis depends on two factors, namely whether the data set has been derived from a reliable analysis and whether the coding instruments were reliable. There are several popular units of analysis used by several scholars such as word count (Deegan and Gordon, 1996; Campbell, 2004 and Wilmshurst and Frost, 2000), sentence count (Milne and Alder, 1999) and page proportions count (Gray et al., 1995). In contrast, frequency and 'high/low' disclosure are lesser used methodologies (Campbell, 2004).

According to several scholars (e.g., Deegan and Gordon, 1996; Milne and Adler, 1999; Unerman, 2000; Guthrie and Abeysekera, 2006), there are some limitations in the content analysis when it is used in examining CED. Unerman (2000) discussed that if a study relies exclusively on annual reports, it may not provide a complete picture of the amount of CED. Simultaneously, the number of characters, words, and sentences ignores non-narrative disclosures such as charts and photographs in the content analysis. Guthrie and Abeysekera (2006) argued that content analysis focuses more on quantifying disclosures than disclosures' quality. Some other scholars argued that it is challenging to capture subjective matters using coding instruments (Wilmshurst and Frost, 2000; Guthrie and Abeysekera, 2006). Thus, it is significant to emphasize the reliability of both data and the coding instruments (Milne and Alder, 1999; Dissanayake et al., 2019).

The extent of environmental disclosure is considered the dependent variable of the study and measured using a "disclosure score" developed based on GRI guidelines (See Appendix). Many scholars recommended this guideline in research. For instance, Kolk (2004) and Clarkson et al. (2010) 
state that GRI related to sustainability disclosures set up to enhance the quality, rigidity and utility. Cormier et al. (2011) recommend GRI as a voluntary disclosure guideline as it provides a broad-based framework for the development of sustainable reporting. Because the GRI index is a global standardized framework, it facilitates data comparison over time and across boundaries and organizations. The "disclosure score" was developed by conducting a content analysis to quantify environmental disclosures to evaluate the extent to which the environmental disclosures were associated with the pre-defined determinants. In giving a disclosure score to a company, specific environmental items were identified following the GRI guidelines, and the disclosure of each aspect was measured using disclosed / not disclosed $(0,1)$ scoring. This scheme allowed a company to score a maximum of 34 points. Consequently, the total CED score for a particular company is calculated as follows:

$$
C E D=\frac{\sum_{i=1}^{n} d i}{\mathrm{n}}
$$

Where:

CED is the corporate environmental disclosure, $d i$ is the disclosure item, and

$\mathrm{n}$ is the number of disclosure items.

\subsection{Model specification:}

Drawing on Powell (2016), we examine CED's possible determinates in Sri Lanka using a Panel Quantile Regression (PQR) model. Contrarily to the conventional linear regression models, which are associated with the least-squares method to estimate the conditional mean of the target across various values of the variables, a PQR model calculates the conditional median of the target (Baum, 2013). By applying a PQR model, our study provides a more inclusive understanding of the determinants of CED in Sri Lanka than prior studies (e.g., Dissanayake and Xydias-Lobo, 2016; Niresh, and Silva, 2018; Dissanayake et al., 2019) that have used different regular linear regression models, such as OLS model and fixed-effects model, for two reasons. First, a PQR model is more rigorous to outliers than the least-squares method. Second, it is deemed a semiparametric because it avoids assumptions linked to the error term's parametric distribution (Cobb-Clark et al., 2016; Powell, 2016).

The PQR model specification can be stated as follows.

$C E D_{i t}=\beta_{0}+\beta_{1} B Z_{i t}+\beta_{2} B I N D_{i t}+\beta_{3} B M_{i t}+\beta_{4} C E O D_{i t}+\beta_{5} F Z_{i t}+\beta_{6} R O E_{i t}+\beta_{7} E P S_{i t}+$ $\beta_{8} I N D U S_{i t}+\varepsilon_{i t}(1)$ 
Where CED is corporate environmental disclosure; B.Z. is board size, BIND is board independence, B.M. is board meeting; CEOD is CEO duality, F.Z. is firm size, ROE is the return on equity, ESP is earnings per shares, INDUS is industry type. See Table 1 for the operational definition of research variables.

\section{Empirical Analysis and Discussion}

\subsection{Univariate Analysis}

Table 2 shows that the mean value of CED is $14.02 \%$ of the 34 items that have been adopted from the GRI checklist. This result is consistent with those of prior CED studies in emerging economies (See Eljayash et al., 2012; Khlif et al., 2015; Habbash, 2016; Gerged et al., 2018; Gerged et al., 2020a,c,d). For instance, Gerged et al. (2018) point out that the average of CED in the MENA region is $13 \%$ of the adopted items. Similarly, Gerged et al.(2020c) suggest that CED has scored a mean value of 14\% in Kuwait. Table 3 suggests that CED in Sri Lanka is associated with an increasing trend over the period 2015-2019. Primarily, the mean value of CED has experienced a growth from 13.65\% (i.e., 4.6 items out of the total of 34 items) in 2013 to $15.75 \%$ (i.e., 5.4 items) in 2019. These findings suggest that listed firms in Sri Lanka established their adherence to the SLCGC best practices requiring that firms' annual reports contain information on their environmental performance to enable their stakeholders to assess how environmental risks and opportunities are recognized, managed, measured, and reported. Nevertheless, when the CED figures in Table 2 are compared to those of their developed counterparts, the relatively low CED manifestation in Sri Lanka seemed to be confirmed. In the United States, for example, CED, in a multi-sectoral study, scored a mean value of $81.8 \%$ of the surveyed items (Matisoff et al., 2013). Likewise, in the U.K., CED recorded an average of 64\% of the adopted items (Barbu et al., 2014). This implies that CED is still deemed at an early stage in Sri Lanka.

\section{INSERT TABLE 2 HERE}

\section{INSERT TABLE 3 HERE}

For CG mechanisms, Table 2 shows that the mean value of board size (B.Z.) is 9.073. The SLCGC of 2013 and 2017 does not state a specific number of directors on a board, though it suggests that every company should be headed by an effective board, which should direct, lead and control the company. Likewise, the mean value of board independence (BIND) is 3.976, indicating companies' adherence to the SLCGC (2013; 2017), requiring that the board include at least three non-executive 
directors. Concerning board meetings frequency, our results are associative of 8.99 average meetings annually throughout the study (2015-2019). This result indicates that the sampled companies' CG practices are in line with the SLCGC (2013; 2017). Specifically, the SLCGC (2017) states that directors should meet regularly at least once in every quarter of a fiscal year in an effort to execute the responsibilities of the board effectively. Also, the results reveal that the CEO-duality (CEOD) is of a mean value of 0.112 . This implies that approximately $88 \%$ of our sample comply with the provisions of SLCGC regarding CEOD. Crucially, SLCGC (2013) and (2017) state that the CEO and Chairman should not have the same duties. Therefore, different people are expected to occupy these two positions to avoid conflicting interests and maintain effective monitoring process for managerial behaviour.

Additionally, Table 2 shows higher levels of profitability as measured by the return on equity (ROE) (0.214) and firm size proxied by the natural logarithm of total assets (i.e., 23.9) as compared with those of Jordanian companies, for example (Gerged, 2020). Finally, almost half of our sampled firms (49\%) are associated with environmentally sensitive (high-profile) companies (INDUS). (See Table 2).

\subsection{Bivariate Analysis}

Table 4 reports the correlations matrix for the primary research variables to test the multicollinearity assumption. It presents the coefficients of correlation. The nature of these coefficients suggests that any residual non-normality in the distribution of the variables might be mild. Moreover, and comparable to the findings of prior studies of a similar nature (e.g., Al-Haddad and Whittington, 2019; Fernandes et al., 2019; Giannarakis et al., 2019; Gerged et al., 2020a,b,c; Gerged, 2020), Table 4 shows statistically significant relationships between CED and both CG variables and firm-specific characteristics. For example, in line with our expectations, board size (B.Z.), board independence (BIND), and board meeting frequency (B.M.) are statistically significant and positively attributed to

CED. By contrast, CEO duality (CEOD) has a statistically negative and significant association with CED. Concerning firm-specific characteristics, Table 4 implies that firm size (F.Z.), profitability (ROE) and industry type (INDUS) are significantly and positively associated with CED in the Sri Lankan context.

In addition, VIF has been separately tested, suggesting that multicollinearity is not deemed as the main concern that can influence the robustness of our findings. 


\section{INSERT TABLE 4 HERE}

\subsection{Panel Quantile Regression analysis}

\subsubsection{CG structures and CED:}

To address the main objective of our study, and following Powell (2016), we distinctively apply the panel quantile regression (PQR) to examine CED's firm-level determinants in the Sri Lankan context. Table 5 shows the findings of estimating a PQR model. For CG influences, Table 5 indicates that board size (B.Z.) is positively attributed to the unweighted CED index (i.e., proxied by GRI checklist) at a $1 \%$ level of significance for the quantiles 0.20 and 0.30 , and from 0.50 to 0.95 quantiles. This implies that $\mathrm{H} 1$ has been accepted statistically. This finding is consistent with the findings of prior studies (e.g., Rao et al., 2012; Liao et al., 2015; Tauringana and Chithambo, 2015; Trireksani and Djajadikerta, 2016; Ezhilarasi and Kabra, 2017; Wang, 2017; Jizi, 2017) that state that a larger sized board can give rise to firms' engagement in CED practices. Theoretically, large boards seemed to be more effective in reducing agency conflicts between managers and shareholders (Ntim, 2016).

Similarly, our findings suggest that board independence (BIND) has a positive association with CED in Sri Lanka at 0.10 median value and from 0.50 to 0.95 quantiles at a $1 \%$ level of significance (see Table 5). This means that $\mathrm{H} 2$ is empirically approved. This result agrees with those of previous work such as Liao et al. (2015) in the U.K., Fernandes et al. (2019) in Brazil, Mudiyanselage (2018) in Sri Lanka and most recently Gerged (2020) in Jordan that conclude that independent directors on boards are expected to encourage greater corporate engagement in CED practices in different settings around the globe. Theoretically speaking, BIND can act as an effective monitoring mechanism to protect shareholders' interests as the value of those directors in the market is highly determined by their role as monitors (Fama and Jensen, 1983). Regarding H3, the findings indicate a positive connotation between board meeting (B.M.) and CED in Sri Lanka at a 1\% level for all quantiles except the 0.90 one. This means that $\mathrm{H} 3$ has been empirically supported. Our result is tied to prior empirical evidence. For example, Primary and Rahardja (2013) and Setyawan and Kamilla (2015) found that the frequency of directors' meeting has a positive impact on CED in Indonesia's context. This implies that B.M.'s frequency is attributable to more effective oversight of the management, which, in turn, seemed to result in more expansive CED practices (Setyawan and Kamilla, 2015).

On the contrary, CEO duality (CEOD) is negatively linked to CED in Sri Lanka at a 1\% level of significance at all quantiles, except 0.2. This gives statistical credibility to H4. From a theoretical view, maintaining the $\mathrm{CEO}$ and chairman positions can increase the risk that the CEO perhaps will take on 
strategies, which consider his/her interests to the firm's detriment (Jensen and Meckling, 1976). Our empirical evidence is in line with prior studies that indicate that CEOD can maximise the conflicts of interest, and thus, can be negatively affecting a firm's transparency process (e.g., Alfraih, 2016; Chau and Gray, 2010; Freitas Neto and Mol, 2017).

\section{INSERT TABLE 5 HERE}

\subsubsection{Firm characteristics and CED}

In relation to firm-specific characteristics, we examine the impact of the industry type, firm size, and profitability on CED in Sri Lanka (See Table 5). Industry type has a significant positive relationship with $\mathrm{CED}$ at $1 \%$ level at all quantiles, except 0.40 quantile. Hence, $\mathrm{H} 5$ can be accepted with statistically enough evidence. It indicates that companies in the high-profile (environmentally sensitive) industries disclose more information than low-profile industries within the Sri Lankan context to reduce their legitimate gap. This finding is in line with Walden and Schwartz (1977) and Rizk et al. (2008). Supportive of legitimacy theory, environmentally sensitive companies would be engaged in more proactive legitimacy-seeking behaviours, in this case through CED, in an attempt to indicate their upholding of the implicit social contract between themselves and societal stakeholders (Deegan et al., 2002; Mahadeo et al., 2011; Burgwal and Vieira, 2014), to key actors, including governmental and nongovernmental actors.

Firm size is positively attributed to CED in Sri Lanka at a 1\% level from 0.10 to 0.30 quantiles, 0.50 to 0.60 , and 0.80 to 0.90 quantiles. Hence, there is a statistically enough evidence to accept H6. This result is consistent with prior researches (e.g., Gray et al., 1995, Burgwal and Vieira, 2014, Cormier et al., 2011; Raar, 2002), though it contradicts the findings of Jariya (2015) suggest a negative relationship between these two variables based on 2011/12 annual reports in the Sri Lankan listed companies. Based upon the tenets of stakeholder theory, large firms are likely to have more stakeholders compared to smaller companies (Jariya, 2015), in order to satisfy this wider variety of powerful stakeholders (Amran and Haniffa, 2011), large-sized firms would thus need to disclose more on the environment (Burgwal and Vieira, 2014). Likewise, the profitability variable shows a correlation which provides statistically significant evidence to explain the relationship between profitability and environmental disclosures. Specifically, profitability, as proxied with ROE, is positively associated with CED in Sri Lanka at $1 \%$ level of significance for the quantiles $0.10,0.30,0.60,0.70,0.95$, and at $5 \%$ level of significance for the quantile 0.20 , and at $10 \%$ for the 0.90 quantiles. This means that this study's results 
provide support to accept the seventh alternative hypothesis (H7). Many studies have found a positive association between the level of environmental disclosures and profitability consistent with the notion of stakeholder theory (e.g., Gray et al., 1995; Akhtaruddin, 2005; Khan et al., 2012; Cormier et al., 2011) that argued that companies tend to disclose more information on the environment to a wide variety of stakeholders if their profitability is high, whereas if their profitability is low, they communicate fewer details of the environment. For instance, Khan et al. (2012) state that profitability allows management to reveal environmental information to stakeholders with freedom and flexibility. 4.3.3. Additional Sensitivity Check

Unlike prior CED studies that have been conducted on the Sri Lankan context (e.g., Jariya, 2015; Dissanayake et al., 2016; Niresh et al., 2018; Mudiyanselage, 2018; Dissanayake et al., 2019; Kengatharan \& Sivakaran, 2019), we employ a 2-step system GMM estimator as a robustness check to ensure that our primary findings were not severely influenced by the possible occurrence of endogeneities (Blundell and Bond, 1998). First, we use Durbin and Wu-Hausman tests to examine the potential incidence of regressors' endogeneity. Theoretically speaking, the independent variables (i.e., firm-level determinants) must not be statistically associated with the error term. Durbin and WuHausman can identify whether the residuals are linked with the independent variables (Ullah et al., 2018; Gerged, 2020). Durbin and Wu-Hausman results indicate that the firm-level determinants are endogenously correlated to the error term rather than exogenously; thus, suggesting that the endogeneity issue seems to be a concern in our study. In this paper, therefore, we address the endogeneity concerns by applying a two-step GMM model.

This study follows prior work (e.g., Gerged, 2020; Gerged et al., 2020c,d; Ullah et al., 2018; Moumen et al., 2015; Reguera-Alvarado et al., 2016; Roberts \& Whited, 2011) by employing a two-step system GMM model as a sensitivity analysis to address the endogeneity concerns arising from the reversal causality relations between the chosen firm-level determinants and CED. Crucially, we incorporate the lagged versions of last year/two-year CED to distinguish between dynamic panel data and static panel data. The specifications of the applied two-step GMM model are as follows:

$$
\begin{gathered}
C E D_{i t}=\alpha_{0}+\beta_{1} C E D_{i t-1}+\beta_{2} C E D_{i t-2}+\beta_{3} B Z_{i t}+\beta_{4} B I N D_{i t}+\beta_{3} B M_{i t}+ \\
\beta_{3} C E O D_{i t}+\beta_{3} F Z_{i t}+\beta_{3} R O E_{i t}+\beta_{3} I N D U S_{i t}+\mu_{i t}+ \\
\varepsilon_{i t}
\end{gathered}
$$


In Equation 2, for instance, $\mathrm{CED}_{\mathrm{it}-1}$ designates one-year lagged $\mathrm{CED}$ (past year's $\mathrm{CED}$ ), and $\mathrm{CED}_{\mathrm{it}-2}$ denotes a second lagged CED, which represents CED in the past two years. These lags are deemed as explanatory variables in the estimation of a two-step system GMM. Statistically, Roodman (2009) states that by including lags of the dependent variable, the GMM model controls the endogeneities by transforming the data internally. A dependent variable's previous value is subtracted from its current one. This internal transformation process reduces the total number of observations and improves the dynamic GMM estimation (Wooldridge, 2016).

Besides, we use a set of post-estimation tests such as the Sargan test and the Arellano-Bond test to examine the validity of GMM estimator and determine whether the instruments (i.e., lags of CED in Equation 2) are appropriately specified (see Table 6). Ullah et al. (2018) state that a critical assumption for the two-step GMM estimator's validity is that instruments (the lags of CED) are exogenous. In other words, if the results of conducting the pre-estimation tests turn out to be nonsignificant, this implies that the instruments are exogenous and valid consequently. Generally speaking, the two-step GMM estimation in this study is deemed an appropriate method to tackle the endogeneity issues in our research study.

\section{INSERT TABLE 6 HERE}

Table 6 presents the results of estimating the 2-step GMM model. The findings of estimating a twostaged GMM are mostly similar to those reported in Model 5. To the extent that our results are statistically comparable to these of the main estimation (i.e., Powell (2016) PQR model), we are equitably confident that our results are robust. 


\section{Conclusion}

This research's primary objective was to examine the determinants of environmental disclosures of the listed companies within a developing country context. For this purpose, the Sri Lankan public listed companies were selected. Our findings contribute to the existing literature in identifying the levels and determinants of environmental disclosures and denoting the extent to which those determinants are associated with the environmental disclosures of publicly listed companies in Sri Lanka using a manually collected dataset in a period spans from 2015 to 2019. Following agency, legitimacy and stakeholder theories, the study has identified different determinants of environmental disclosures, namely board characteristics (i.e., B.Z., BIND, B.M., and CEOD), industry type, company size and profitability, and developed a similar number of hypotheses for empirical investigation.

Our study results suggest a growing trend in CED practices in Sri Lanka from 2015 to 2019, although it is still deemed to be at an early stage compared with other developed counterparts. This study also provides new empirical evidence that suggests that board structures are significant determinants of CED in emerging economies. Specifically, B.Z., BIND, and B.M. are positively correlated to CED, whereas, as expected, CEOD has a negative association with CED in the context of the study. From an agency theory perspective, these findings imply that corporate compliance with the SLCGC of 2017 appeared to enhance the monitoring processes in place to mitigate managerial opportunism whilst simultaneously expanding (and enabling) firm-level engagement in CED, resulting ultimately in contributing to the reduction of conflicts of interest and the diminishing of information asymmetries between managers and shareholders, pertaining to environmental disclosures.

Furthermore, this study's findings revealed that companies operating in high profile industries (i.e. environmentally sensitive sectors) disclose more environmental information than those that belong to a low profile or less environmentally sensitive sectors. In line with legitimacy-seeking behaviours, supportive of the strategic legitimacy perspective (Oliver, 1991), these findings indicate that companies operating in environmentally sensitive industries, are engaged in the more pro-active pursuit of legitimacy and CED provides them with a useful tool to be utilized for that purpose. As suggested by Brown and Deegan (1998), by engaging in CED, such high-profile companies are not only protecting their social contract in Sri Lanka but also are signalling to key institutional actors, such as governmental and non-governmental (e.g. environmentalists) actors, the voluntary measures they have been undertaking to uphold their social contract. CED provides these high-profile companies with the ability to seek legitimacy pragmatically, thereby mitigating any future operational risks in the country. 
The findings also displayed enough statistical evidence to support the stakeholder view, as the findings indicate a positive association between the size of the company and their level of environmental disclosures. As such, larger firms appear to engage more proactively in CED due to their need to satisfy a wide variety of stakeholders. While this finding differs from previous studies from the same context - i.e. Sri Lanka, where a negative relationship has been found (Jariya, 2015) in this regard, it is possible that the differences in the findings can be accrued to a proactive move towards CED by Sri Lankan companies, thereby acknowledging the importance of environmental transparency as a mechanism for pro-active stakeholder engagement. This view is further supported by findings that have indicated the influence of CED on firm profitability in Sri Lanka, indicating that positive customer perception about the CED of Sri Lankan companies leading to competitive market advantages drives the protracted CED behaviours of listed Sri Lankan companies.

Our results reiterate the crucial need for more concerted efforts to be undertaken by Colombo Stock Exchange (CSE), national regulatory institutions, and other non-governmental organisations, including professional accounting bodies, such as the Institute of Chartered Accountants (ICA) in Sri Lanka, to further propagate and promote substantive CG reforms, mandating CED. Such an action will not only foster more CED by listed companies in the country but most importantly, provide companies with the ability to reduce extant legitimacy gaps, by the provisioning of environmental information to key stakeholders. However, any institutionalised changes in this regard should also be approached with caution by policymakers, as CED could be adopted in a superficial manner as opposed to it engendering substantive internalised changes within Sri Lanka companies' environmental strategies.

The nature of this study, however, does present certain limitations. Firstly, it included only those companies who were reporting on the environment by adopting the GRI Index to measure quality and externally assured dependent variable (i.e., environmental disclosures). Hence, the research findings cannot be generalized to a great extent, specifically regarding companies that use a selfregulated corporate environmental disclosures framework. Further research would have to be carried out to expand the disclosure score to accommodate self-regulated corporate environmental disclosure frameworks, thereby examining both standardized and unstandardized environmental disclosures.

Furthermore, the study primarily focused on the number of environmental disclosures rather than the quality aspects, and it investigated the determinants of environmental disclosures that affect the length 
of disclosures. Hence, it is assumed in this study that the GRI Index based corporate environmental disclosures provides quality environmental disclosures. Thus, future researchers have the opportunity to conduct studies on corporate environmental disclosures by incorporating both a quantity and qualitative research approaches such as content analysis based on word counts, lines and pages as suggested by many earlier researchers (Gray et al., 1995; Deegan and Gordon, 1996; Milne and Alder, 1999; Wilmshurst and Frost, 2000; Campbell, 2004).

As noted above, this study considered only the quantitative aspects of the disclosures based on GRI guidelines (i.e., whether disclosed or not) whereas it ignored the qualitative elements. Robert and Koeplin (2007) found that high profile industries have used GRI reporting for greenwashing specifically to build their corporate reputation. As a solution, Raar (2002) suggested providing qualitative weights in developing the disclosure score to assess transparency and the quality of CEDs. Since the study found that companies in high profile industries keen on providing more CED, future researchers could focus on qualitative aspects of reporting and study whether companies use CED to build corporate reputations, rather than reporting in a balanced manner.

Finally, the study measured environmental disclosures using annual reports of the companies to collect data due to the lack of separate reports on the environment within the Sri Lankan context. The annual report may not be the only disclosure medium used by companies, particularly in developed countries (Cowan \& Gadenne, 2005). 


\section{Appendix:}

CED index based on the GRI checklist

\begin{tabular}{|c|c|}
\hline \multicolumn{2}{|c|}{ Corporate Environmental Disclosure Score } \\
\hline & Materials \\
\hline 1 & The material used by weight or volume used by the organization \\
\hline \multirow[t]{2}{*}{2} & Percentage of recycled input materials used by the organization \\
\hline & Energy \\
\hline 3 & Energy consumption within the organization \\
\hline 4 & Energy consumption outside of the organization \\
\hline 5 & Energy intensity \\
\hline 6 & Reduction of energy consumption \\
\hline \multirow[t]{2}{*}{7} & Reduction in energy requirements of products and services \\
\hline & Water \\
\hline 8 & Total water withdrawal by sources \\
\hline 9 & Water sources significantly affected by the withdrawal of water \\
\hline \multirow[t]{2}{*}{10} & Percentage and total volume of water recycled and reused \\
\hline & Biodiversity \\
\hline 11 & $\begin{array}{l}\text { Operational sites owned, leased, managed in, or adjacent to, protected areas and areas of high biodiversity value outside } \\
\text { protected areas }\end{array}$ \\
\hline 12 & $\begin{array}{l}\text { Description of significant impacts of activities, products, and services on biodiversity in protected areas and areas of } \\
\text { high biodiversity value outside protected areas }\end{array}$ \\
\hline 13 & Habitats protected or restricted \\
\hline \multirow[t]{2}{*}{14} & $\begin{array}{l}\text { Total number of iucn red list species and national conservation list species with habitats in areas affected by operations, } \\
\text { by the level of extinction risk }\end{array}$ \\
\hline & Emission \\
\hline 15 & Direct greenhouse gas (GHG) emissions \\
\hline 16 & Energy indirect greenhouse gas (GHG) emissions \\
\hline 17 & Other indirect greenhouse gas (GHG) emissions \\
\hline 18 & Greenhouse gas (GHG) emissions intensity \\
\hline 19 & Reduction of greenhouse gas (GHG) emissions \\
\hline 20 & Emissions of ozone-depleting substances (ods) \\
\hline \multirow[t]{2}{*}{21} & Nox, sox, and other significant air emissions \\
\hline & Effluents and Waste \\
\hline 22 & Total water discharge by quality and destination \\
\hline 23 & Total weight of waste by type and disposal method \\
\hline 24 & Total number and volume of significant spills \\
\hline 25 & $\begin{array}{l}\text { Weight of transported, imported, exported, or treated waste deemed hazardous under the terms of the basel } \\
\text { convention } 2 \text { annex i, ii, iii, and viii, and percentage of transported waste shipped internationally }\end{array}$ \\
\hline \multirow[t]{2}{*}{26} & $\begin{array}{l}\text { Identity, size, protected status, and biodiversity value of water bodies and related habitats significantly affected by the } \\
\text { organization's discharges of water and runoff }\end{array}$ \\
\hline & Product and Services \\
\hline 27 & The extent of impact mitigation of environmental impacts of products and services \\
\hline \multirow[t]{2}{*}{28} & Percentage of products sold and their packaging materials that are reclaimed by category \\
\hline & Compliance \\
\hline \multirow[t]{2}{*}{29} & $\begin{array}{l}\text { The monetary value of significant fines and the total number of non-monetary sanctions for non-compliance with } \\
\text { environmental laws and regulations }\end{array}$ \\
\hline & Transport \\
\hline \multirow[t]{2}{*}{30} & $\begin{array}{l}\text { Significant environmental impacts of transporting products and other goods and materials for the organization's } \\
\text { operations, and transporting members of the workforce }\end{array}$ \\
\hline & Overall \\
\hline \multirow[t]{2}{*}{31} & Total environmental protection expenditures and investments by type \\
\hline & Supplier Environmental Assessment \\
\hline 32 & Percentage of new suppliers that were screened using environmental criteria \\
\hline \multirow[t]{2}{*}{33} & Significant actual and potential negative environmental impacts in the supply chain and actions taken \\
\hline & Environmental grievance \\
\hline 34 & $\begin{array}{l}\text { Number of grievances about environmental impacts filed, addressed and resolved through formal grievance } \\
\text { mechanisms }\end{array}$ \\
\hline
\end{tabular}




\section{References}

Adhariani, D. and du Toit, E. (2020), "Readability of sustainability reports: evidence from Indonesia", Journal of Accounting in Emerging Economies, Vol. 10 No. 4, pp. 621-636.

Agyei, S.K. and Yankey, B. (2019), "Environmental reporting practices and performance of timber firms in Ghana: Perceptions of practitioners", Journal of Accounting in Emerging Economies, Vol. 9 No. 2, pp. 268-286.

Ahmed, K., Hossain, M., \& Adams, M. B. (2006). "The effects of board composition and board size on the informativeness of annual accounting earnings". Corporate Governance: An International Review, Vol. 14 No. 5, pp. 418-431.

Akbas, H. E. (2016). "The relationship between board characteristics and environmental disclosure: Evidence from Turkish listed companies". South-East European Journal of Economics and Business, Vol. 11 No. 2, pp. 7-19.

Akhtaruddin, M. (2005), "Corporate Mandatory Disclosure Practices in Bangladesh", The International Journal of Accounting, Vol. 40 No. 4, pp. 399-422.

Akisik, O. and Gal, G. (2011), "Sustainability in businesses, corporate social responsibility, and accounting standards: An empirical study", International Journal of Accounting \& Information Management, Vol. 19 No. 3, pp.304-324.

Albitar, K., Hussainey, K., Kolade, N., \& Gerged, A. (2020), "ESG disclosure and firm performance before and after I.R.: The moderating role of governance mechanisms" The International Journal of Accounting \& Management Information, Vol. 28 No. 2, pp. 1-20. (In press).

Alewine, H.C. and Stone, D.N. (2013), "How does environmental accounting information influence attention and investment?", International Journal of Accounting and Information Management, Vol. 21 No. 1, pp.22-52.

Alfraih, M. M. (2016). "The effectiveness of the board of directors' characteristics in mandatory disclosure compliance". Journal of Financial Regulation and Compliance, Vol. 24 No. 2, pp. 154-176.

Al-Gamrh, B., Ku Ismail, K.N.I., Ahsan, T. and Alquhaif, A. (2020), "Investment opportunities, corporate governance quality, and firm performance in the UAE", Journal of Accounting in Emerging Economies, Vol. 10 No. 2, pp. 261-276.

Al-Haddad, L. and Whittington, M. (2019). "The impact of corporate governance mechanisms on real and accrual earnings management practices: evidence from Jordan". Corporate Governance, Vol. 19 No. 6, pp. 1167-1186.

Amran, A., \& Devi, S. S. (2007), "Corporate Social Reporting in Malaysia: An Institutional Perspective", World Review of Entrepreneurship, Management and Sustainable Development, Vol. 3 No. 1, pp. 20-36. 
Amran, A., \& Haniffa, R. M. (2011), "Evidence in Development of Sustainability Reporting: A Case of a Developing Country", Business Strategy and the Environment, Vol. 20 No. 3, pp. 141-156.

Amran, A., \& Siti-Nabiha, A. K. (2009), "Corporate Social Reporting in Malaysia: A case of mimicking the West or succumbing to local pressure", Social Responsibility Journal, Vol. 5 No. 3, pp. 358-375.

Ashforth, B. E., \& Gibbs, B. W. (1990). "The double-edge of organizational legitimation". Organization Science, Vol. 1 No. 2, pp. 177-194.

Azim, M., Ahmed, E., \& D'Netto, B. (2011), "Corporate Social Disclosure in Bangladesh: A study of the Financial Sector", International Review of Business Research Papers, Vol. 7 No. 2, pp. 37-55.

Barbu, E. M., Dumontier, P., Feleagă, N., \& Feleagă, L. (2014). "Mandatory environmental disclosures by companies complying with IASs/IFRSs: The cases of France, Germany, and the U.K". The International Journal of Accounting, Vol. 49 No. 2, pp. 231-247.

Baum, Christopher F. (2013), “Quantile Regression” (accessed April 22, 2020), http:// fmwww.bc.edu/EC-C/S2013/823/EC823.S2013.nn04.slides.pdf.

Beddewela, E., \& Herzig, C. (2013), "Corporate Social Reporting by MNCs' Subsidiaries in Sri Lanka", Accounting Forum, pp.135-149.

Beiner, S., Drobetz, W., Schmid, F., \& Zimmermann, H. (2004). "Is board size an independent corporate governance mechanism? " Kyklos, Vol. 57 No. 3, pp. 327-356.

Belal, A. R. (2001), "A Study of Corporate Social Disclosures in Bangladesh", Managerial Auditing Journal, Vol. 16 No. 5, pp. 274-289.

Belal, A. R., \& Cooper, S. (2011), "The Absence of Corporate Social Responsibility Reporting in Bangladesh", Critical Perspectives on Accounting, Vol. 22 No. 7, pp. 654-667.

Belal, A. R., \& Momin, M. (2009). "Corporate Social Reporting (CSR) in Emerging Economies: A Review and Future Direction", Research in Accounting in Emerging Economies, Vol. 9 No. 1, pp. 119-143.

Belal, A. R., Kabir, M. R., Cooper, S., Dey, P., Khan, N. A., Rahman, T., \& Ali, M. (2010), "Corporate Environmental and Climate Change Disclosures: Empirical Evidence from Bangladesh", Research in Accounting in Emerging Economies, Vol. 10, pp. 145-167.

Bhattarai, B. P. (2014), "The Relationship between Environmental Accounting and Firm Performance: An Empirical Analysis of Selected Listed Companies in Nepal Stock Exchange, Nepal", International Journal of Engineering \& Management Technology, Vol. 2 No. 4, pp. 9-23.

Blundell, R., Bond, S. (1998). "Initial conditions and moment restrictions in dynamic panel data models". Journal of Econometrics, Vol. 87 No. 1, pp. 115-143. 
Brown, N., \& Deegan, C. (1998), "The Public Disclosure of Environmental Performance Information - A Dual Test of Media Agenda Setting Theory and Legitimacy Theory", Accounting and Business Research, pp. 21-41.

Burgwal, D.V.D. and Vieira, R.J.O. (2014), "Environmental disclosure determinants in Dutch listed companies", Revista Contabilidade \& Finanças, Vol. 25 No. 64, pp. 60-78.

Campbell, D. J. (2004), "A longitudinal and Cross-sectional Analysis of Environmental Disclosure in U.K. Companies- a Research Note", The British Accounting Review, Vol. 36 No. 1, pp. 107-117.

Chau, G., \& Gray, S. J. (2010). "Family ownership, board independence and voluntary disclosure: Evidence from Hong Kong". Journal of International Accounting, Auditing and Taxation, Vol. 19 No. 2, pp. 93-109.

Clarkson, P.M., Overell, M.B. and Chapple, L. (2011), "Environmental reporting and its relation to corporate environmental performance", Abacus, Vol. 47 No. 1, pp.27-60.

Cobb-Clark, D. A., Kassenboehmer, S. C., \& Sinning, M. G. (2016). "Locus of control and savings". Journal of Banking \& Finance, Vol. 73 No. 1, pp. 113-130.

Cormier, D., Ledoux, M., \& Magnan, M. (2011), "The Informational Contribution of Social and Environmental Disclosures for Investors", Management Decision, Vol. 49 No. 8, pp. 1276 - 1304.

Cowan, S., \& Gadenne, D. (2005), "Australian Corporate Environmental Reporting: A Comparative Analysis of Disclosure Practices Across Voluntary and Mandatory Disclosure Systems", Journal of Accounting \& Organizational Change, Vol. 1 No. 2, pp. 165-179.

D'Amico, E., Coluccia, D., Fontana, S., \& Solimene, S. (2016). "Factors influencing corporate environmental disclosure". Business Strategy and the Environment, Vol. 25 No. 3, pp. 178-192.

Deegan, C., \& Gordon, B. (1996), "A study of the Environmental Disclosure Practices of Australian Corporations", Accounting and business research, vol. 26 No. 3, pp. 187-199.

Deegan, C., Rankin, M., \& Tobin, J. (2002), "An Examination of the Corporate Social and Environmental Disclosures of BHP from 1983-1997: A test of Legitimacy Theory", Accounting, Auditing \& Accountability Journal, Vol. 15 No. 3, pp. 312-343.

Diab, A. and Metwally, A.B.M. (2020), "Institutional complexity and CSR practices: evidence from a developing country", Journal of Accounting in Emerging Economies, Vol. 10 No. 4, pp. 655-680.

Dissanayake, D., Tilt, C. and Xydias-Lobo, M. (2016). "Sustainability reporting by publicly listed companies in Sri Lanka". Journal of Cleaner Production, Vol. 129, pp.169-182.

Dissanayake, D., Tilt, C. and Qian, W. (2019), "Factors influencing sustainability reporting by Sri Lankan companies", Pacific Accounting Review, Vol. 31 No. 1, pp. 84-109. 
Eljayash, K. M., James, K., \& Kong, E. (2012). "The quantity and quality of environmental disclosure in annual reports of national oil and gas companies in the Middle East and North Africa". International Journal of Economics and Finance, Vol. 4 No. 10, pp. 201-217.

Ezhilarasi, G., \& Kabra, K. C. (2017). "The impact of corporate governance attributes on environmental disclosures: Evidence from India". Indian Journal of Corporate Governance, Vol. 10 No. 2, pp. 24-43.

Fama, E. F. (1980). "Agency Problems and the theory of the firm". Journal of Political Economy, Vol. 88 No. 2, pp. 288-307.

Fama, E. F., \& Jensen, M. C. (1983). "Agency problems and residual claims". The Journal of Law and Economics, Vol. 26 No. 2, pp. 327-349.

Fernandes, S.M., Bornia, A.C. and Nakamura, L.R. (2019). "The influence of boards of directors on environmental disclosure", Management Decision, Vol. 57 No. 9, pp. 2358-2382.

Freitas Neto, R. M. D., \& Mol, A. L. R. (2017). "Determinants of the roles boards of directors have in Brazilian companies". Revista de Administração Contemporânea, Vol. 21 No. SPE, pp. 63-83.

Gao, S., Heravi, S., \& Xiao, J. Z. (2005), "Determinants of Corporate Social and Environmental Reporting in Hong Kong: A Research Note", Accounting Forum, Vol. 29 No. 2, pp. 233-242.

Gerged, A. M., Cowton, C. J., \& Beddewela, E. S. (2018), "Towards sustainable development in the Arab Middle East and North Africa region: A longitudinal analysis of environmental disclosure in corporate annual reports", Business Strategy and the Environment, Vol. 27 No. 4, pp. 572-587.

Gerged, A. M., \& Agwili, A. (2020). "How corporate governance affect firm value and profitability? Evidence from Saudi financial and non-financial listed firms". International Journal of Business Governance and Ethics, Vol. 14 No. 2, pp. 144-165.

Gerged, A. M., Beddewela, E. S., \& Cowton, C. J. (2020a). "Is corporate environmental disclosure associated with firm value? A multi-country study of Gulf Cooperation Council firms". Business Strategy and the Environment, Forthcoming DOI: 10.1002/BSE.2642

Gerged, A., \& Elheddad, M. (2020). "How can national governance affect education quality in Western Europe? " International Journal of Sustainability in Higher Education, Vol. 21 No. 3, pp. 413-426.

Gerged, A., Al-Haddad, L. and Al-Hajri, M. (2020c). "Is earnings management associated with corporate environmental disclosure? Evidence from Kuwaiti listed firms", Accounting Research Journal, Vol. 33 No. 1, pp. 167-185.

Gerged, A., M. (2020). Factors affecting corporate environmental disclosure in emerging markets the role of corporate governance structures. Business Strategy and the Environment, Forthcoming: DOI 10.1002/BSE.2642 
Gerged, A., M., Albitar, K., and Alhaddad, L.(2021a). "Corporate environmental disclosure and earnings management - the moderating role of corporate governance structures". International Journal of Finance and Economics, Forthcoming.

Gerged, A., M., Beddewela, E., and Cowton, C. (2021b). "Does country-level governance quality affect corporate environmental disclosure? Evidence from the Gulf Cooperation Council nations". International Journal of Finance and Economics, Forthcoming.

Gerged, A., M., Babikir, B., M., \& Elmghaamez, I. (2020b). "Did corporate governance compliance have an impact on auditor selection and quality? " Evidence from FTSE 350. International Journal of Disclosure and Governance, Vol. 17 No. 2, pp. 51-60.

Gerged, A., M., Matthews, L., \& Elheddad, M. (2020d). "Mandatory Disclosure, Greenhouse Gas Emissions and the Cost of Equity Capital: UK Evidence of a U-shaped Relationship". Business Strategy and the Environment Forthcoming.

Giannarakis, G., Andronikidis, A., \& Sariannidis, N. (2019). "Determinants of environmental disclosure: investigating new and conventional corporate governance characteristics". Annals of Operations Research, pp. 1-19.

Gray, R. (2000). "Current developments and trends in social and environmental auditing, reporting and attestation: a review and comment". International journal of auditing, V1. 4 No. 3, pp. 247-268.

Gray, R., Kouhy, R., \& Lavers, S. (1995), "Constructing a Research Database of Social and Environmental Reporting by U.K. Companies", Accounting, Auditing \& Accountability Journal, Vol. 8 No. 2, pp. 78-101.

Guthrie, J., \& Abeysekera, I. (2006), "Content Analysis of Social, Environmental Reporting: What is New?", Journal of Human Resource Costing \& Accounting, Vol. 10 No. 2, pp. 114-126.

Habbash, M. (2016). Corporate governance and corporate social responsibility disclosure: evidence from Saudi Arabia. Journal of Economic and Social Development, Vol. 3 No. 1, pp. 87-103.

Hogan, J. and Lodhia, S. (2011), "Sustainability reporting and reputation risk management: an Australian case study", International Journal of Accounting \& Information Management, Vol. 19 No. 3 , pp. 267-287.

IPS. (2014), "Sri Lanka State of the Economy 2014: Rising Asia - Opportunities and Challenges for Sri Lanka". Colombo, Sri Lanka: Institute of Policy Studies of Sri Lanka.

Jamali, D., Safieddine, A. M., \& Rabbath, M. (2008). "Corporate governance and corporate social responsibility synergies and interrelationships". Corporate Governance: An International Review, Vol. 16 No. 5, pp. 443-459.

Jariya, A. I. (2015), "Environmental Disclosures in Annual Reports of Sri Lankan Corporate: A Content Analysis", Journal of Emerging Trends in Economics and Management Sciences, 6(8), 350-357.

Jensen, M. C., \& Meckling, W. H. (1976). "Theory of the Firm: Managerial Behavior, Agency Costs and Ownership Structure". Journal of Financial Economics, Voil. 3 No. 4, pp. 305-360. 
Jizi, M. (2017). "The influence of board composition on sustainable development disclosure". Business Strategy and the Environment, Vol. 26 No. 5, pp. 640-655.

Kengatharan, L., \& Sivakaran, T. (2019). "Impact of corporate governance practices on corporate social responsibility: evidence from listed banks, finance and insurance companies in Sri Lanka". Asia-Pacific Management Accounting Journal, Vol. 14 No. 2, pp. 115-138.

Khan, A., Muttakin, M. B., \& Siddiqui, J. (2012), "Corporate governance and corporate social responsibility disclosures: evidence from an emerging economy", Journal of Business Ethics, vol. 114 No. 2, pp. 207-223.

Khlif, H., Guidara, A., \& Souissi, M. (2015). "Corporate social and environmental disclosure and corporate performance". Journal of Accounting in Emerging Economies, Vol. 5 No. 1, pp. 51-69.

Kolk, A. (2004), "A Decade of Sustainability Reporting: Developments and Significance", International Journal Environment and Sustainable Development, Vol. 3 No. 1, pp .51-64.

KPMG. (2013), "The KPMG Survey of Corporate Responsibility Reporting 2013", KPMG International.

Krippendorff, K., (2013), "Content Analysis: An Introduction to its Methodology (3 ${ }^{\text {rd }}$ ed.)", SAGE Publications, United States.

Liao, L., Luo, L., \& Tang, Q. (2015). "Gender diversity, board independence, environmental committee and greenhouse gas disclosure". The British Accounting Review, Vol. 47 No. 7, pp. 409424.

Litic, K. B. (2008), "Environmental Reporting as a Communications Tool: A Question of Enforcement?", Journal of Environmental Law, Vol. 20 No. 1, pp. 69 - 85.

Lydenberg, S., Rogers, J., \& Wood, D. (2010), "From Transparency to Performance: Industry - Based Sustainability Reporting on Key Issues", The Hauser Center for Nonprofit Organizations at Harvard University and initiative for responsible investment.

Mahadeo, J. D., Oogarah-Hanuman, V., \& Soobaroyen, T. (2011), "Changes in Social and Environmental Reporting Practices in an Emerging Economy (2004-2007): Exploring the Relevance of Stakeholder and Legitimacy Theories", Accounting Forum, Vol. 35 No. 3, pp. 158175.

Mathuva, D.M., Tauringana, V. and Owino, F.J.O. (2019), "Corporate governance and the timeliness of audited financial statements: The case of Kenyan listed firms", Journal of Accounting in Emerging Economies, Vol. 9 No. 4, pp. 473-501.

Matisoff, D. C., Noonan, D. S., O'Brien, J. J. (2013). "Convergence in environmental reporting: assessing the Carbon Disclosure Project". Business Strategy and the Environment, Vol. 22 No. 5, pp. 285-305. 
Matuszak, Ł., Różańska, E. and Macuda, M. (2019), "The impact of corporate governance characteristics on banks' corporate social responsibility disclosure: Evidence from Poland", Journal of Accounting in Emerging Economies, Vol. 9 No. 1, pp. 75-102.

Milne, M. J., \& Adler, R. W. (1999), "Exploring the Reliability of Social and Environmental Disclosures Content Analysis", Accounting, Auditing \& Accountability Journal, Vol. 12 No. 2, pp. 237-256.

Mohmed, A., Flynn, A. and Grey, C. (2019), "The link between CSR and earnings quality: evidence from Egypt", Journal of Accounting in Emerging Economies, Vol. 10 No. 1, pp. 1-20.

Moumen, N., Othman, H. B., Hussainey, K. (2015). "The value relevance of risk disclosure in annual reports: evidence from MENA emerging markets". Research in International Business and Finance, Vol. 34 No. 2, pp. 177-204.

Mudiyanselage, N. C. S. R. (2018). "Board involvement in corporate sustainability reporting: evidence from Sri Lanka". Corporate Governance: The International Journal of Business in Society, Vol. 18 No. 6, pp. 1042-1056.

Niresh, J. A., \& Silva, W. H. E. (2018). "The extent of corporate social responsibility disclosure practices: evidence from the banks, finance and insurance sector in Sri Lanka". Global Journal of Management and Business Research, Vol. 17 No. 2, pp. 2249-4588.

Ntim, C. G. (2016). "Corporate governance, corporate health accounting, and firm value: The case of HIV/AIDS disclosures in Sub-Saharan Africa". The International Journal of Accounting, Vol. 51 No. 2, pp. 155-216.

Ntim, C. G., \& Soobaroyen, T. (2013). "Black economic empowerment disclosures by South African listed corporations: The influence of ownership and board characteristics". Journal of Business Ethics, Vol. 116 No. 1, pp. 121-138.

Oliver, C. (1991). "Strategic Responses to Institutional Processes". The Academy of Management Review, Vol. 16 No. 1, pp. 145-179.

Orazalin, N. and Mahmood, M. (2019), "Determinants of GRI-based sustainability reporting: evidence from an emerging economy", Journal of Accounting in Emerging Economies, Vol. 10 No. 1, pp. $140-164$.

Powell, D. (2016). "Quantile regression with nonadditive fixed effects". Quantile Treatment Effects, pp. $1-28$.

Prado-Lorenzo, J. M., \& Garcia-Sanchez, I. M. (2010). "The role of the board of directors in disseminating relevant information on greenhouse gases". Journal of Business Ethics, Vol. 97 No. 3, pp. 391-424. 
Pramanik, A. K., Shil, N. C., \& Das, B. (2008). "Corporate environmental reporting: An emerging issue in the corporate world". International Journal of Business and Management, Vol. 3 No. 12, pp. 146-154.

Primary, A., \& Rahardja. (2013). "Effect of Good Corporate Governance and Environmental Performance on Environmental Disclosure (Empirical Study on Manufacturing and Mining Company Listed in Indonesia Stock Exchange and Incorporated in PROPER Year 2009-2011) ". Journal of Accounting Diponegoro, Vol. 2 No. 3, pp. 1-14

Qu, W., Leung, P., \& Cooper, B. (2013), "A Study of Voluntary Disclosure of Listed Chinese Firms A Stakeholder Perspective", Managerial Auditing Journal, Vol. 28 No. 3, pp. 261-294.

Raar, J. (2002), "Environmental Initiatives: Towards Triple-bottom Line Reporting", Corporate Communications: An International Journal, Vol. 7 No. 3, pp. 169-183.

Rajeshwaran N. \& Ranjani R.P.C. (2013), "An Investigation of Voluntary Environmental Reporting Practices of Sri Lankan Listed Companies", Annual Research Sessions, Faculty of Graduate Studies, University of Colombo.

Rao, K., Kathyayini, Tilt, C. A., \& Lester, L. H. (2012), "Corporate Governance and Environmental Reporting: An Australian Study", Corporate Governance: The international journal of business in society, Vol. 12 No. 2, pp. 143-163.

Reguera-Alvarado, N., Blanco-Oliver, A., Martín-Ruiz, D. (2016). "Testing the predictive power of PLS through cross-validation in banking", Journal of Business Research, Vol. 69 No. 10, pp. 46854693.

Rizk, R., Dixon, R., \& Woodhead, A. (2008), "Corporate Social and Environmental Reporting: A Survey of Disclosure Practices in Egypt", Social Responsibility Journal, Vol. 4 No. 3, pp. 306-323.

Robert, C. B. (1991), "Environmental Disclosures: A Note on Reporting Practices in Mainland Europe", Accounting, Auditing \& Accountability Journal, Vol. 4 No. 3, pp. 62-71.

Roberts, D. H., \& Koeplin, J. P. (2007), "Sustainability Reporting Practices In Portugal: Greenwashing Or Triple Bottom Line?", International Business \& Economics Research Journal, Vol. 6 No. 9, pp. 2940.

Roberts, M. R., Whited, T. M. (2011). "Endogeneity in empirical corporate finance. In Constantinides, M. and Stulz, R. (Eds.) ", Handbook of the Economics of Finance, Vol. 2 No. 1, pp. 493-572.

Roberts, R. W. (1992), "Determinants of Corporate Social Responsibility Disclosure: An Application of Stakeholder Theory", Accounting, Organizations and Society, vol. 17 No. 6, pp. 595-612

Roodman, D. (2009). "How to do xtabond2: an introduction to difference and system GMM in Stata". The Stata Journal, Vol. 9 No. 1, pp. 86-136. 
Said, R., Zainuddin, Y., \& Haron, H. (2009), "The Relationship between Corporate Social Responsibility Disclosure and Corporate Governance Characteristics in Malaysian Public Listed Companies", Social Responsibility Journal, Vol. 5 No. 2, pp. 212-228.

Salancik, G. R., \& Pfeffer, J. (1978). "A social information processing approach to job attitudes and task design". Administrative science quarterly, pp. 224-253.

Salem, I.H., Ayadi, S.D. and Hussainey, K. (2019), "Corporate governance and risk disclosure quality: Tunisian evidence", Journal of Accounting in Emerging Economies, Vol. 9 No. 4, pp. 567-602.

Salem, R. A., Ezeani, E., Gerged, A. M., Usman, M., Alqatamin, R. M. (2020). "Does the quality of voluntary disclosure constrain earnings management in emerging economies? Evidence from Middle Eastern and North African Banks", International Journal of Accounting and Information Management. Forthcoming, https://doi.org/10.1108/IJAIM-07-2020-0109

Sarivudeen, A.L., \& Sheham, A. M. (2013), "Corporate Governance Practices and Environmental Reporting: A Study of Selected Listed Companies in Sri Lanka", Proceedings of Annual International Research Conference on Innovative Perspective in Business, Finance and Information Management, South Eastern University of Sri Lanka, 2017, pp. 284-291

Setyawan, H., \& Kamilla, P. (2015). "Impact of corporate governance on corporate environmental disclosure: Indonesian evidence". In International Conference on Trends in Economics, Humanities and Management, pp. 13-18.

SLCGC. (2013). "Code of Best Practices on Corporate Governance 2013”. Available at: https://cdn.cse.lk/pdf/Corporate Governance Code 2013 book.pdf (Accessed in October 2020).

SLCGC. (2017). "Code of Best Practices on Corporate Governance 2017”. Available at: https://www.casrilanka.com/casl/images/stories/2017/2017 pdfs/code of best practice o n_corporate_governance_2017_final_for_web.pdf (Accessed in October 2020).

Smith, M., Yahya, K., \& Amiruddin, M. (2007), "Environmental Disclosure and Performance Reporting in Malaysia", Asian Review of Accounting, Vol. 15 No. 2, pp. 185-199.

Suchman, M. C. (1995), "Managing legitimacy: Strategic and institutional approaches. Academy of Management", The Academy of Management Review, Vol. 2 No. 3, pp. 571- 610.

Sumiani, Y., Haslinda, Y., \& Lehman, G. (2007), "Environmental Reporting in a Developing Country: A Case Study on Status and Implementation in Malaysia", Journal of Cleaner Production, Vol. 15 No. 10, pp. 895-901.

Suttipun, M., \& Stanton, P. (2012), "Determinants of Environmental Disclosure in Thai Corporate Annual Reports", International Journal of Accounting and Financial Reporting, Vol. 2 No. 1, pp. 99115. 
Tauringana, V., \&Chithambo, L. (2015). "The effect of DEFRA guidance on greenhouse gas disclosure". The British Accounting Review, Vol. 47 No. 4, pp. 425-444.

Tilt, C. A. (2009), "Corporate Responsibility, Accounting and Accountants" Professional Perspectives of Corporate Social Responsibilities, pp. 11-32.

Tregidga, H., Milne, M., \&Kearins, K. (2009), "Organisational Legitimacy and Social and Environmental Reporting Research: The Potential of Disclosure Analysis", Accounting, Auditing and Accountability Journal, pp. 1 -19.

Trireksani, T., \& Djajadikerta, H. G. (2016). "Corporate governance and environmental disclosure in the Indonesian mining industry". Australasian Accounting, Business and Finance Journal, Vol. 10 No. 1, pp. 18-28.

Ullah, S., Akhtar, P., Zaefarian, G. (2018). "Dealing with endogeneity bias: the generalized method of moments (GMM) for panel data". Industrial Marketing Management, Vol. 71, pp. 69-78.

Unerman, J. (2000), "Methodological Issues-Reflections on Quantification in Corporate Social Reporting Content Analysis", Accounting, Auditing \& Accountability Journal, Vol. 13 No. 5, pp. 667681.

Walden, W. D., \& Schwartz, B. N. (1997), "Environmental Disclosures and Public Policy Pressure", Journal of Accounting and Public Policy, Vol. 16, pp. 125-154.

Wang, M.-C. (2017). "The relationship between firm characteristics and the disclosure of sustainability reporting". Sustainability (Switzerland), Vol. 9 No. 4, pp. 624-637.

Wang, Z., Ali, M.J., \& Al - Akra, M., (2013), "Value relevance of voluntary disclosure and the global financial crisis: evidence from China", Managerial Auditing Journal, Vol. 28 No. 5, pp. 444-468.

Welbeck, E.E.S., Owusu, G.M.Y., Simpson, S.N.Y. and Bekoe, R.A. (2020), "CSR in the telecom industry of a developing country: employees' perspective", Journal of Accounting in Emerging Economies, Vol. 10 No. 3, pp. 447-464.

Wilmshurst, T. D., \& Frost, G. R. (2000), "Corporate Environmental Reporting", Accounting, Auditing \& Accountability Journal, Vol. 13 No. 1, pp. 10-26.

Wooldridge, J. M. (2016). "Introductory Econometrics: A Modern Approach", (Sixth Edition). Toronto: Nelson Education.

World Bank. (2015), "Sri Lanka Economic Update 2015", Washinton, D.C: The World Bank.

$\mathrm{Yu}, \quad$ M. and Zhao, R. (2015), "Sustainability and firm valuation: an international investigation", International Journal of Accounting \& Information Management, Vol. 23 No. 3, pp. 289-307. 
Table 1:

The Operational Definitions of Research Variables

\begin{tabular}{|c|c|}
\hline Variable & Operational Definition \\
\hline & Dependent Variables \\
\hline \multirow[t]{2}{*}{ CED } & $\begin{array}{l}\text { The "CED" score was developed by conducting a content analysis to quantify environmental disclosures } \\
\text { the extent to which the environmental disclosures were associated with the pre-defined determinants. } \\
\text { disclosure score to a company, specific environmental items were identified following the GRI guidelin } \\
\text { disclosure of each aspect was measured using disclosed / not disclosed }(0,1) \text { scoring. This scheme allowed } \\
\text { to score a maximum of } 34 \text { points. }\end{array}$ \\
\hline & Independent Variables \\
\hline B.Z. & Board size, equal to a total number of directors on the board \\
\hline BIND & Board independence, equal to the number of independent directors on the board \\
\hline \multirow{3}{*}{$\begin{array}{l}\text { B.M. } \\
\text { CEOD }\end{array}$} & Board meeting, equal to the number of meetings the board of directors has during a giv \\
\hline & CEO-duality, is a dummy variable equals one if the same person holds CEO and the ch \\
\hline & Control variables \\
\hline F.Z. & $\begin{array}{l}\text { Firm size, equal to the natural log of total assets. Total assets measured similar to the studies conducted by } \\
\text { (2007) and Burgwal and Vieira (2014) company size as at that period of the chosen sample (2015 to 2019). }\end{array}$ \\
\hline ROE & $\begin{array}{l}\text { Return on equity, measured as net income divided by equity. This measurement for profitability is also cons } \\
\text { Smith et al. (2007). }\end{array}$ \\
\hline INDUS & $\begin{array}{l}\text { Following Burgwal and Vieira (2014), the industries in which public listed companies operate have been cla } \\
\text { high-profile and low-profile companies based on the environmental sensitivity which is measured in ter } \\
\text { consumer visibility, high level of political risk and concentrated intense competition. For this purpose, ind } \\
\text { ranked according to the Industry Classification Benchmark Sector (ICB-Sector), which classifies ten indus } \\
\text { on sustainability issues (see Lydenberg et al., 2010). Lydenberg et al. (2010) identify former five industries as } 1 \\
\text { industries (i.e., oil and gas, basic material, industrials, consumer goods and healthcare) and latter five indust } \\
\text { profile industries (i.e., consumer services, telecommunication, utilities, financials and technologies). Wit } \\
\text { Lankan context, CSE follows a } 20 \text { sectors classification. Thus, the sectors, namely beverages, food an } \\
\text { chemicals and farms, construction, manufacturing, oil palms, plantations, footwear and textile, power a } \\
\text { motors, healthcare, have been identified as those which can be categorized into high-profile industri } \\
\text { remaining industries (i.e., banking and finance, diversified, hotels and travels, land and property, invest } \\
\text { services, stores supply, telecommunication and trading and I.T.) into low-profile industries. High-profile and } \\
\text { industries were given a score of "1" and "0", respectively. }\end{array}$ \\
\hline
\end{tabular}


Table 2:

Descriptive Statistics

\begin{tabular}{lrrrrr}
\hline Variable & Obs & Mean & Std. Dev. & Min & Max \\
\hline CED & 205 & 14.205 & 8.886 & 0 & 34 \\
B.Z. & 205 & 9.073 & 1.922 & 5 & 13 \\
BIND & 205 & 3.976 & 1.564 & 2 & 9 \\
B.M. & 205 & 8.99 & 5.127 & 2 & 29 \\
CEOD & 205 & 0.112 & 0.316 & 0 & 1 \\
ROE & 205 & .214 & .539 & -0.358 & 3.943 \\
EPS & 205 & 37.703 & 235.43 & -24.03 & 3353 \\
INDS & 205 & 0.493 & 0.501 & 0 & 1 \\
F.Z. & 205 & 23.993 & 1.716 & 20.614 & 27.958 \\
\hline
\end{tabular}

Note: The research variables are operationally defined in Table 1. 
Table 3:

Descriptive Statistics of Research Variables on a Yearly Basis.

\begin{tabular}{|c|c|c|c|c|c|c|c|c|}
\hline & Year/Variable & CED & B.Z. & BIND & B.M. & CEOD & ROE & INDS \\
\hline$\overline{2015}$ & Mean & 13.56 & 9.07 & 3.88 & 9.20 & .12 & .216 & .49 \\
\hline & Median & 12.00 & 10.00 & 3.00 & 8.00 & .00 & .118 & .00 \\
\hline & Std. Deviation & 9.408 & 1.752 & 1.288 & 5.582 & .331 & .477 & .506 \\
\hline & Minimum & 3 & 6 & 2 & 2 & 0 & .0312 & 0 \\
\hline & Maximum & 34 & 13 & 7 & 29 & 1 & 3.135 & 1 \\
\hline 2016 & Mean & 13.68 & 9.12 & 4.10 & 8.95 & .10 & .243 & .49 \\
\hline & Median & 12.00 & 9.00 & 3.00 & 7.00 & .00 & .134 & .00 \\
\hline & Std. Deviation & 9.782 & 1.952 & 1.562 & 4.939 & .300 & .600 & .506 \\
\hline & Minimum & 0 & 5 & 2 & 3 & 0 & -.047 & 0 \\
\hline & Maximum & 34 & 13 & 8 & 22 & 1 & 3.94 & 1 \\
\hline 2017 & Mean & 13.88 & 9.29 & 3.98 & 8.90 & .10 & .229 & .49 \\
\hline & Median & 12.00 & 9.00 & 4.00 & 7.00 & .00 & .156 & .00 \\
\hline & Std. Deviation & 8.286 & 1.914 & 1.525 & 4.673 & .300 & .569 & .506 \\
\hline & Minimum & 0 & 5 & 2 & 3 & 0 & -.35784 & 0 \\
\hline & Maximum & 34 & 13 & 9 & 18 & 1 & 3.621 & 1 \\
\hline 2018 & Mean & 14.17 & 9.10 & 3.98 & 9.10 & .10 & .209 & .49 \\
\hline & Median & 13.00 & 9.00 & 4.00 & 8.00 & .00 & .124 & .00 \\
\hline & Std. Deviation & 7.976 & 2.010 & 1.620 & 5.195 & .300 & .527 & .506 \\
\hline & Minimum & 0 & 6 & 2 & 4 & 0 & -.049 & 0 \\
\hline & Maximum & 34 & 13 & 9 & 25 & 1 & 3.42 & 1 \\
\hline 2019 & Mean & 15.73 & 8.78 & 3.95 & 8.80 & .12 & .171 & .49 \\
\hline & Median & 13.00 & 9.00 & 3.00 & 6.00 & .00 & .081 & .00 \\
\hline & Std. Deviation & 9.113 & 2.031 & 1.843 & 5.437 & .331 & .535 & .506 \\
\hline & Minimum & 4 & 6 & 2 & 2 & 0 & -.228 & 0 \\
\hline & Maximum & 34 & 13 & 9 & 25 & 1 & 3.457 & 1 \\
\hline
\end{tabular}

Note: The Variables are operationally defined in Table 1. 
Table 4:

Matrix of correlations

\begin{tabular}{llllllll}
\hline Variables & $\mathbf{( 1 )}$ & $\mathbf{( 2 )}$ & $\mathbf{( 3 )}$ & $\mathbf{( 4 )}$ & $\mathbf{( 5 )}$ & $\mathbf{( 6 )}$ & $\mathbf{( 7 )}$ \\
\hline (1) CED & & & & & & & \\
(2) B.Z. & $0.152^{* *}$ & & & & & \\
(3) BIND & $0.230^{* *}$ & $0.581^{* *}$ & & & & & \\
(4) B.M. & $0.139^{* *}$ & $0.476^{* *}$ & $0.397^{* *}$ & & & & \\
(5) CEOD & $-0.084^{* *}$ & $0.091^{* *}$ & $0.084^{* *}$ & $0.078^{* *}$ & & & \\
(6) ROE & $0.018^{* *}$ & $0.206^{* *}$ & $0.108^{* *}$ & $0.118^{* *}$ & $0.117^{* *}$ & & \\
(7) INDS & $0.008^{* *}$ & $0.267^{* *}$ & $0.354^{* *}$ & $0.549^{* *}$ & $0.175^{* *}$ & $0.102^{* *}$ & \\
(8) F.Z. & $0.068^{* *}$ & $0.384^{* *}$ & $0.567^{* *}$ & $0.600^{* *}$ & $0.034^{* *}$ & $0.023^{* *}$ & $0.485^{* *}$ \\
\hline
\end{tabular}

Note: Variables are operationally defined in Table $1 .{ }^{* *}$ shows significance at the 0.05 level. 
Table 5:

Panel quantile regression results of the determinants of CED in Sri Lanka

\begin{tabular}{lcccccccc}
\hline & $(1)$ & $(2)$ & $(3)$ & $(4)$ & $(5)$ & $(6)$ & $(7)$ & \\
& CED & CED & CED & CED & CED & CED & CED & C \\
& 0.10 & 0.20 & 0.30 & 0.40 & 0.50 & 0.60 & 0.70 \\
\hline B.Z. & .084 & $.62^{* * *}$ & $.653^{* * *}$ & .352 & $1.035^{* * *}$ & $.817^{* * *}$ & $1.524^{* * *}$ & 1.6 \\
& $(.19)$ & $(.201)$ & $(.182)$ & $(.459)$ & $(.214)$ & $(.234)$ & $(.43)$ & $($. \\
BIND & .028 & .251 & $.542^{* * *}$ & .770 & $1.657^{* * *}$ & $2.17^{* * *}$ & $3.319^{* * *}$ & 2.1 \\
& $(.403)$ & $(.191)$ & $(.15)$ & $(.643)$ & $(.256)$ & $(.156)$ & $(.399)$ & $($. \\
B.M. & $.605^{* * *}$ & $.599^{* * *}$ & $.655^{* * *}$ & $.865^{* * *}$ & $.565^{* * *}$ & $.57^{* * *}$ & $.487^{* * *}$ & .25 \\
& $(.039)$ & $(.037)$ & $(.101)$ & $(.329)$ & $(.048)$ & $(.078)$ & $(.139)$ & $($. \\
CEOD & $-1.178^{* * *}$ & -.261 & $-.1337^{* * *}$ & $-1.185^{* * *}$ & $-3.138^{* * *}$ & $-2.948^{* * *}$ & $-10.56^{* * *}$ & -3.6 \\
& $(.429)$ & $(.29)$ & $(.454)$ & $(.604)$ & $(.618)$ & $(.507)$ & $(2.344)$ & $($. \\
ROE & $1.893^{* * *}$ & $1.31^{* *}$ & $1.335^{* * *}$ & 5.565 & .978 & $1.2^{* * *}$ & $5.671^{* * *}$ & .83 \\
& $(.600)$ & $(.587)$ & $(.363)$ & $(5.33)$ & $(1.128)$ & $(.213)$ & $(2.006)$ & $($. \\
INDS & $2.101^{* * *}$ & $1.827^{* * *}$ & $2.212^{* *}$ & 3.984 & $1.483^{* * *}$ & $2.749^{* * *}$ & $8.064^{* * *}$ & 5.3 \\
& $(.499)$ & $(.545)$ & $(1.017)$ & $(6.11)$ & $(.419)$ & $(.424)$ & $(1.569)$ & $($. \\
F.Z. & $1.051^{* * *}$ & $.384^{* * *}$ & $.541^{* *}$ & 1.335 & $.373^{* *}$ & $.444^{* *}$ & .303 & .6 \\
& $(.197)$ & $(.137)$ & $(.254)$ & $(1.061)$ & $(.176)$ & $(.196)$ & $(.266)$ & $($. \\
Observations & 205 & 205 & 205 & 205 & 205 & 205 & 205 & 205 \\
\hline
\end{tabular}

Note: Variables are operationally defined in Table 1 . Standard errors are in parentheses ${ }^{* * *} \mathrm{p}<.01,{ }^{* *} \mathrm{p}<.05,{ }^{*} \mathrm{p}<.1$ 
Table 6:

Two-Step System GMM

\begin{tabular}{|c|c|}
\hline & $(1)$ \\
\hline & CED \\
\hline \multirow[t]{2}{*}{ L.CED } & $.481 * * *$ \\
\hline & $(.041)$ \\
\hline \multirow[t]{2}{*}{ L2.CED } & $.044^{*}$ \\
\hline & $(.023)$ \\
\hline \multirow[t]{2}{*}{ B.Z. } & $.422 * * *$ \\
\hline & $(.152)$ \\
\hline \multirow[t]{2}{*}{ BIND } & $1.755^{* * *}$ \\
\hline & $(.12)$ \\
\hline \multirow[t]{2}{*}{ B.M. } & $.508 * * *$ \\
\hline & $(.103)$ \\
\hline \multirow[t]{2}{*}{ CEOD } & $-6.194 * * *$ \\
\hline & $(2.356)$ \\
\hline \multirow[t]{2}{*}{ ROE } & 1.566 \\
\hline & $(1.154)$ \\
\hline \multirow[t]{2}{*}{ INDS } & $5.356^{* * *}$ \\
\hline & $(1.359)$ \\
\hline \multirow[t]{2}{*}{ F.Z. } & $.705^{* * *}$ \\
\hline & $(.081)$ \\
\hline Observations & 123 \\
\hline Arellano-Bond test for AR (1) in first differences (P-value) & 0.002 \\
\hline Arellano-Bond test for AR (2) in first differences (P-value) & 0.323 \\
\hline Sargan test of overid. restrictions: & 73.44 \\
\hline Durbin (score) chi2 & $1.724(p=0.300)$ \\
\hline Wu-Hausman F $(2,818)$ & $0.800(\mathrm{p}=0.408)$ \\
\hline
\end{tabular}

Note: Variables are operationally defined in Table 1. Standard errors are in parentheses ${ }^{* * *} p<.01,{ }^{* *} p<.05, * p<.1$ 